\title{
KAJIAN PRESERVASI DI INDONESIA
}

Testiani Makmur', Depi Suadi², Dafrizal Samsudin ${ }^{3}$

('Mahasiswa Doktoral IImu Perpustakaan dan Informasi, UIN Sunan Kalijaga Yogyakarta)

('Dosen Komputer dan Informasi IAIN Kerinci)

('Dosen Ilmu Komunikasi-Fakultas IImu Komunikasi Universitas Islam Riau)

email:Testianisr28@gmail.com,depisuadi9545@gmail.com,dafrizal@comm.uir.ac.id

\section{Abstrak}

Kajian ini dijalankan menggunakan metode studi kepustakaan dengan berbasis pada jurnal-jurnal sains informasi dan kepustakaan berakreditasi sinta berjumlah 25 jurnal. Kajian ini mendapati 49 artikel tentang preservasi di Indonesia diterbitkan sejak tahun 2010-2020. Terdapat 10 topik preservasi yaitu pelestarian naskah kuno atau manuskrip, pelestarian budaya, preservasi arsip, preservasi bahan pustaka, pelestarian pengetahuan dan informasi, preservasi photo, preservasi dokumen, preservasi majalah, preservasi digital, dan konsep preservasi yang didapatkan dari jurnal-jurnal seperti berikut: Record and Library Journal, Jurnal Kajian Informasi \& Perpustakaan, Media Pustakawan dan Khizanah Al-Hikmah: Jurnal IImu Perpustakaan, Informasi dan Kearsipan, Shaut Al-Maktabah: Jurnal Perpustakaan, Arsip dan Dokumentasi, ANUVA: Jurnal Kajian Budaya, Perpustakaan dan Informasi, Khazanah: Jurnal Pengembangan Kearsipan, Jurnal Ilmu Informasi, Perpustakaan dan Kearsipan sertab Jurnal Iqra', Jurnal IImiah Kepustakawanan "Libraria", Jurnal PUBLIS, Bibliotech: Jurnal IImu Perpustakaan dan Informasi, Al Maktabah: Jurnal Kajian Ilmu dan Perpustakaan, JIPI (Jurnal Ilmu Perpustakaan dan Informasi), PUSTABIBLIA: Journal of Library and Information Science) dan Jurnal IPI (Ikatan Pustakawan Indonesia). Dapat disimpulkan bahwa masih sedikit kajian preservasi yang diterbitkan pada jurnal-jurnal sains informasi dan kepustakaan berakreditasi SINTA. Kajian preservasi di Indonesia sudah memiliki keberagaman topik kajian.

\section{Abstract}

This study was carried out using the literature study method based on information science journals and literature accredited with SINTA totaling 25 journals. This study found 49 articles on preservation in Indonesia published from 2010-2020. There are 10 preservation topics, namely preservation of ancient manuscripts, cultural preservation, archive preservation, library material preservation, preservation of knowledge and information, photo preservation, document preservation, magazine preservation, digital preservation, and preservation concepts obtained from journals such as the following: Record and Library Journal, Jurnal Kajian Informasi \& Perpustakaan, Media Pustakawan dan Khizanah Al-Hikmah: Jurnal IImu Perpustakaan, Informasi dan Kearsipan, Shaut Al-Maktabah: Jurnal Perpustakaan, Arsip dan Dokumentasi, ANUVA: Jurnal Kajian Budaya, Perpustakaan dan Informasi, Khazanah: Jurnal Pengembangan Kearsipan, Jurnal IImu Informasi, Perpustakaan dan Kearsipan sertab Jurnal Iqra', Jurnal IImiah Kepustakawanan "Libraria", Jurnal PUBLIS, Bibliotech: Jurnal IImu Perpustakaan dan Informasi, AI Maktabah: Jurnal Kajian IImu dan Perpustakaan, JIPI (Jurnal IImu Perpustakaan dan Informasi), PUSTABIBLIA: Journal of Library and Information Science) dan Jurnal IPI (Ikatan Pustakawan Indonesia). It can be concluded that there are still few preservation studies published in SINTA-accredited information science journals and literature. Preservation studies in Indonesia already have a variety of study topics.

\section{Kata Kunci:}

Preservasi, Jurnal, Terakreditasi, Sinta, Indonesia

\section{Keywords:}

Preservation, Journal, Accredited, Sinta, Indonesia 


\section{A. PENDAHULUAN}

Preservasi merupakan upaya untuk memperbaiki, mencegah, menyelamat, mempertahankan, memperpanjang usia dari sisi informasi maupun fisik dari kerusakan. Seperti diutarakan Dureau dan Clements tujuan dari preservasi untuk melestarikan muatan informasi ilmiah dan fisik asli bahan pustaka ataupun arsip, agar dapat digunakan dalam bentuk seutuhnya (Dureau dan Clements: 1986, 2). Selaras disebutkan Eden dan Feather (1997) esensi praktek preservasi yaitu memastikan materi informasi dalam keadaan baik untuk dimanfaatkan atau diakses kapanpun, sedangkan praktek preservasi mencakup kebijakan dan strategi. Bicara preservasi maka perlu juga meninjau kajian preservasi di Indonesia. Karena kajian preservasi di Indonesia beberapa tahun terakhir merupakan wilayah dominan ditelaah oleh peneliti, pustakawan dan mahasiswa sebagai tema kajian skripsi, tesis serta artikel ilmiah. Hal ini dapat dibuktikan dari publikasi dengan tema preservasi beragam-ragam. Misalnya (1) preservasi naskah kuno yang dikaji oleh Siti Wahdah (2019) berjudul Preservasi Naskah Kuno (Manuskrip) Kalimantan Selatan (Studi Kasus pada Dinas Perpustakaan dan Kearsipan Provinsi dan Museum Lambung Mangkurat Kalimantan Selatan), (2) preservasi bahan pustakaa yang telaah oleh Machsun Rifauddin dan Bagas Aldi Pratama (2020) dengan tema Strategi Preservasi Dan Konservasi Bahan Pustaka di Dinas Kearsipan dan Perpustakaan Kabupaten Trenggalek, preservasi arsip dieksplolari oleh Eko Noprianto dan I Ketut Gunadi Adiguna (2021) dengan tajuk kajian Preservasi Arsip Foto Digital Individual: Kajian Pada Mahasiswa MIP UGM Angkatan 2018-2019, (4) preservasi bangunan bersejarah dibahas oleh Udjianto Pawitro (2015) dengan topik Preservasi-Konservasi Bangunan Bersejarah dan Pengelolaan Kawasan Kota Lama.

Keberagaraman tema kajian preservasi tersebut, pada umumnya dipublikasikan dalam jurnal. Misalnya jurnal-jurnal berafliasi_pada sains informasi dan kepustakaan. Jurnal-jurnal berafliasi pada sains informasi dan kepustakaan terbit di Indonesia ada 90 jurnal (Nashihuddin: 2015). Kontributornya terdiri dari universitas, institusi dan organisasi. Journal universitas didapat dari UPT perpustakaan universitas, fakultas, jurusan dan prodi. Journal Institusi seperti lembaga peneliti, lembaga studi, kementerian dan lembaga Negara (Perpustakaan umum daerah) tingkat nasional, provinsi dan kabupaten. Journal organisasi didapat dari organisasi profesi seperti asosiasi pustakawan. Dari ke 90 jurnal perpustakaan frekuensi terbitannya berbeda-beda, tidak semua memiliki versi E-Journal dan hanya beberapa jurnal terakreditasi sinta.

\section{B. TINJAUAN TEORITIS}

Database sinta merupakan database berfungsi untuk menilai kinerja jurnal-jurnal berdasarkan standard berakreditasi dan sitasi (lemlit.trisakti. ac.id: 2020) serta berisi pula daftar jurnal-jurnal nasional terakreditasi. Jurnal sains informasi dan kepustakaan terakreditasi sinta per tanggal 30 Oktober 2020 dapat dilihat pada tabel 1:

Tabel 1 Jurnal Sains Informasi dan Kepustakaan yang Terakreditasi Sinta

\begin{tabular}{|c|c|c|c|}
\hline No & Nama Jurnal & Penerbit Jurnal & $\begin{array}{c}\text { Terakredi- } \\
\text { tasi Sinta }\end{array}$ \\
\hline 1 & $\begin{array}{c}\text { Berkala Ilmu } \\
\text { Perpustakaan dan } \\
\text { informasi } \\
\text { https://jurnal.ugm. } \\
\text { ac.id/v3/bip/ }\end{array}$ & $\begin{array}{c}\text { Universitas } \\
\text { Gadjah Mada }\end{array}$ & Sinta 2 \\
\hline 2 & $\begin{array}{c}\text { Khizanah Al- } \\
\text { Hikmah: Jurnal } \\
\text { Ilmu Perpustakaan, } \\
\text { Informasi dan } \\
\text { Kearsipan } \\
\text { journal.uin- } \\
\text { alauddin.ac.id/ } \\
\text { index.php/ } \\
\text { khizanah-al- } \\
\text { hikmah/index }\end{array}$ & Universitas Islam & Sinta 2 \\
\hline
\end{tabular}




\begin{tabular}{|c|c|c|c|}
\hline 3 & $\begin{array}{c}\begin{array}{c}\text { Jurnal Kajian } \\
\text { Informasi \& } \\
\text { Perpustakaan }\end{array} \\
\text { http://jurnal.unpad. } \\
\text { ac.id/jkip/index }\end{array}$ & $\begin{array}{l}\text { Universitas } \\
\text { Padjadjaran }\end{array}$ & Sinta 2 \\
\hline 4 & $\begin{array}{c}\text { Baca: Jurnal } \\
\text { Dokumentasi dan } \\
\text { Informasi } \\
\frac{\text { https://jurnalbaca. }}{\text { pdii.lipi.go.id/index. }} \\
\text { php/baca }\end{array}$ & $\begin{array}{l}\text { Lembaga Ilmu } \\
\text { Pengetahuan } \\
\text { Indonesia }\end{array}$ & Sinta 2 \\
\hline 5 & $\begin{array}{l}\text { Pustakaloka: Jurnal } \\
\text { Kajian Informasi dan } \\
\text { Perpustakaan } \\
\begin{array}{l}\frac{\text { http://jurnal. }}{\text { iainponorogo. }} \\
\frac{\text { ac.id/index.php/ }}{\text { pustakaloka }}\end{array}\end{array}$ & IAIN Ponorogo & Sinta 3 \\
\hline 6 & $\begin{array}{l}\text { Lentera Pustaka: } \\
\text { Jurnal Kajian Ilmu } \\
\text { Perpustakaan, } \\
\text { Informasi dan } \\
\text { Kearsipan } \\
\\
\text { https://ejournal. } \\
\text { undip.ac.id/index. } \\
\text { php/lpustaka }\end{array}$ & $\begin{array}{l}\text { Universitas } \\
\text { Dipenogoro }\end{array}$ & Sinta 3 \\
\hline 7 & $\begin{array}{c}\text { Jurnal LIBRARIA: } \\
\text { Jurnal Perpustakaan } \\
\frac{\text { https://journal. }}{\text { iainkudus.ac.id/ }} \\
\frac{\text { index.php/Libraria/ }}{\text { index }}\end{array}$ & STAIN Kudus & Sinta 3 \\
\hline 8 & $\begin{array}{c}\text { Edulib : Journal } \\
\text { of Library and } \\
\text { Information Science } \\
\frac{\text { https://ejournal. }}{\text { upi.edu/index.php/ }} \\
\underline{\text { edulib }}\end{array}$ & $\begin{array}{l}\text { Universitas } \\
\text { Pendidikan } \\
\text { Indonesia }\end{array}$ & Sinta 3 \\
\hline 9 & $\begin{array}{c}\begin{array}{c}\text { Record and Library } \\
\text { Journal }\end{array} \\
\text { https://e-journal. } \\
\text { unair.ac.id/RLJ }\end{array}$ & $\begin{array}{l}\text { Universitas } \\
\text { Airlangga }\end{array}$ & Sinta 3 \\
\hline & 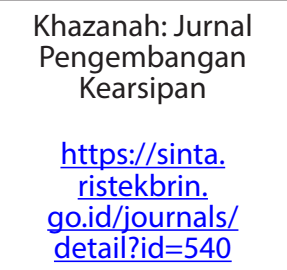 & $\begin{array}{l}\text { Universitas } \\
\text { Gadjah Mada }\end{array}$ & Sinta 3 \\
\hline 10 & $\begin{array}{c}\text { JIPI: Jurnal IImu } \\
\text { Perpustakaan dan } \\
\text { Informasi } \\
\text { http://jurnal.uinsu. } \\
\text { ac.id/index.php/jipi }\end{array}$ & $\begin{array}{c}\text { Universitas Islam } \\
\text { Negeri Sumatera } \\
\text { Utara }\end{array}$ & Sinta 4 \\
\hline
\end{tabular}

\begin{tabular}{|c|c|c|c|}
\hline 11 & $\begin{array}{l}\text { Tik Ilmenu: Jurnal } \\
\text { Ilmu Perpustakaan } \\
\text { dan Informasi } \\
\text { http://journal. } \\
\frac{\text { iaincurup.ac.id/ }}{\text { index.php/TI }}\end{array}$ & IAIN Curup & Sinta 4 \\
\hline 12 & $\begin{array}{l}\text { IQRO: Jurnal } \\
\begin{array}{c}\text { Perpustakaan dan } \\
\text { Informasi }\end{array} \\
\frac{\text { http://jurnal.uinsu. }}{\frac{\text { ac.id/index.php/ }}{\text { iqra/index }}}\end{array}$ & $\begin{array}{c}\text { Universitas IsIma } \\
\text { Negeri Sumatera } \\
\text { Utara }\end{array}$ & Sinta 4 \\
\hline 13 & $\begin{array}{l}\text { ANUVA: Jurnal } \\
\text { Kajian Budaya, } \\
\text { Perpustakaan dan } \\
\text { Informasi } \\
\\
\frac{\text { https://ejournal2. }}{\text { undip.ac.id/index. }} \\
\text { php/anuva/index }\end{array}$ & $\begin{array}{c}\text { Universitas } \\
\text { Diponegoro }\end{array}$ & Sinta 4 \\
\hline 14 & $\begin{array}{c}\begin{array}{c}\text { Jurnal IImu } \\
\text { Informasi, } \\
\text { Perpustakaan dan } \\
\text { Kearsipan }\end{array} \\
\text { http://jipk.ui.ac.id/ } \\
\text { index.php/jipk }\end{array}$ & $\begin{array}{l}\text { Universitas } \\
\text { Indonesia }\end{array}$ & Sinta 4 \\
\hline 15 & $\begin{array}{c}\text { PUSTABIBLIA: } \\
\text { Journal of Library } \\
\text { and Information } \\
\text { Science } \\
\begin{array}{c}\text { https://inferensi. } \\
\text { iainsalatiga. } \\
\text { ac.id/index.php/ } \\
\text { pustabiblia/index }\end{array} \\
\end{array}$ & IAIN SALATIGA & Sinta 4 \\
\hline 16 & $\begin{array}{l}\text { PUBLIS (Publication } \\
\text { Library and } \\
\text { Information } \\
\text { Science) } \\
\frac{\text { http://journal.umpo. }}{\frac{\text { ac.id/index.php/ }}{\text { PUBLIS }}}\end{array}$ & $\begin{array}{c}\text { Universitas } \\
\text { Muhammadiyah } \\
\text { Ponorogo }\end{array}$ & Sinta 4 \\
\hline 17 & $\begin{array}{c}\text { Journal of } \\
\text { Documentation and } \\
\text { Information Science } \\
\frac{\text { http://jodis.isipii. }}{\text { org/index.php/ }} \\
\frac{\text { odis/pages/view/ }}{\text { indexing }}\end{array}$ & $\begin{array}{c}\text { Ikatan } \\
\text { Sarjana IImu } \\
\text { Perpustakaan } \\
\text { dan Informasi } \\
\text { Indonesia }\end{array}$ & Sinta 4 \\
\hline 18 & $\begin{array}{l}\text { Bibliotech : Jurnal } \\
\text { Ilmu Perpustakaan } \\
\text { dan Informasi } \\
\frac{\text { academicjournal. }}{\text { yarsi.ac.id/index. }} \\
\text { php/bibliotech }\end{array}$ & Universitas Yarsi & Sinta 4 \\
\hline
\end{tabular}




\begin{tabular}{|c|c|c|c|}
\hline 19 & $\begin{array}{l}\text { Diplomatika: Jurnal } \\
\text { Kearsipan Terapan } \\
\underline{\text { https://jurnal.ugm. }} \\
\underline{\text { ac.id/diplomatika }}\end{array}$ & $\begin{array}{l}\text { Universitas } \\
\text { Gadjah Mada }\end{array}$ & Sinta 4 \\
\hline 20 & $\begin{array}{l}\text { BIBLIOTIKA: Jurnal } \\
\text { Kajian Perpustakaan } \\
\text { dan Informasi } \\
\underline{\text { http://journal2. }} \\
\frac{\text { um.ac.id/index.php/ }}{\text { bibliotika }}\end{array}$ & $\begin{array}{l}\text { Universitas } \\
\text { Negeri Malang }\end{array}$ & Sinta 5 \\
\hline 21 & $\begin{array}{c}\text { Shaut Al- } \\
\text { Maktabah : Jurnal } \\
\text { Perpustakaan, Arsip } \\
\text { dan Dokumentasi } \\
\frac{\text { https://rjfahuinib. }}{\text { org/index.php/ }} \\
\underline{\text { shaut }}\end{array}$ & $\begin{array}{l}\text { UIN Imam Bonjol } \\
\text { Padang }\end{array}$ & Sinta 5 \\
\hline 22 & $\begin{array}{l}\text { Media Pustakawan } \\
\text { https://ejournal. } \\
\text { perpusnas.go.id/mp }\end{array}$ & $\begin{array}{l}\text { Perpustakaan } \\
\text { Nasional }\end{array}$ & Sinta 5 \\
\hline 23 & $\begin{array}{c}\begin{array}{c}\text { Jurnal IPI (Ikatan } \\
\text { Pustakawan } \\
\text { Indonesia) }\end{array} \\
\text { https://ejournal. } \\
\text { perpusnas.go.id/mp }\end{array}$ & $\begin{array}{c}\text { Ikatan } \\
\text { Pustakawan } \\
\text { Indonesia (IPI) } \\
\text { Pusat }\end{array}$ & Sinta 5 \\
\hline 24 & $\begin{array}{l}\text { Al Maktabah : Jurnal } \\
\text { Kajian Ilmu dan } \\
\text { Perpustakaan } \\
\frac{\text { https://ejournal. }}{\text { iainbengkulu. }} \\
\frac{\text { ac.id/index.php/ }}{\text { almaktabah }}\end{array}$ & $\begin{array}{l}\text { Institut Agama } \\
\text { Islam Negeri } \\
\text { Bengkulu }\end{array}$ & Sinta 6 \\
\hline 25 & $\begin{array}{c}\begin{array}{c}\text { Jurnal Pustaka } \\
\text { Budaya }\end{array} \\
\frac{\text { https://journal. }}{\text { unilak.ac.id/index. }} \\
\text { php/pb }\end{array}$ & $\begin{array}{c}\text { Universitas } \\
\text { Lancang Kuning }\end{array}$ & Sinta 6 \\
\hline
\end{tabular}

Sumber: sinta.ristekbrin.go.id, 2020.

Dari dua puluh lima jurnal-jurnal sains informasi dan kepustakaan terakreditasi sinta, maka perlu meninjau tema kajian preservasi. Apakah kesemua jurnal-jurnal tersebut menerbitkan tema presersvasi dan bagaimana trend kajian preservasi. Untuk mengungkap hal tersebut, maka dilakukan dengan cara penelusuran selama satu bulan (1 Oktober sampai 30 Oktober 2020) pada masingmasing website jurnal-jurnal sains informasi dan kepustakaan terakreditasi sinta dengan kata kunci preservasi.

\section{Hasil Dan Pembahasan}

Berdasarkan penelusuran pada masingmasing portal jurnal-jurnal sains informasi dan kepustakaan terakreditasi sinta, diperoleh 49 artikel berkenaan dengan preservasi ataupun pelestarian. Lebih rinci seperti pada tabel 2 berikut:

Tabel 2 Judul Kajian Preservasi di Jurnal Sains Informasi dan Kepustakaan Terakreditasi Sinta

\begin{tabular}{|c|c|c|c|c|}
\hline No & Nama Penulis & Judul Artikel & Diterbitkan Oleh & $\begin{array}{l}\text { Tahun } \\
\text { Terbit }\end{array}$ \\
\hline 1 & Zulfikar Zen & $\begin{array}{l}\text { Cacah ulang, penyiangan } \\
\text { dan preservasi }\end{array}$ & \begin{tabular}{|l|} 
Jurnal IImu \\
Informasi, \\
Perpustakaan dan \\
Kearsipan
\end{tabular} & 2013 \\
\hline 2 & $\begin{array}{l}\text { Anton Purwanto } \\
\text { Putra }\end{array}$ & $\begin{array}{l}\text { Preservasi Digital Arsip } \\
\text { Peta (Blue Print) di Kantor } \\
\text { Arsip Universitas } \\
\text { Indonesia }\end{array}$ & $\begin{array}{l}\text { Jurnal IImu } \\
\text { Informasi, } \\
\text { Perpustakaan dan } \\
\text { Kearsipan }\end{array}$ & 2013 \\
\hline 3 & Irvan Muliyadi & \begin{tabular}{|l|} 
Revitalisasi Peran Stake \\
Holder Perpustakaan \\
Sebagai Upaya Pelestarian \\
Warisan Budaya \\
Bangsa Dalam Rangka \\
Membangun Kerjasama \\
Perpustakaan di Kawasan \\
Asia Tenggara
\end{tabular} & $\begin{array}{l}\text { Khizanah al- } \\
\text { Hikmah: Jurnal } \\
\text { Ilmu Perpustakaan, } \\
\text { Informasi dan } \\
\text { Kearsipa }\end{array}$ & 2013 \\
\hline 4 & Andi Ibrahim & $\begin{array}{l}\text { Perawatan Dan } \\
\text { Pelestarian Bahan Pustaka }\end{array}$ & $\begin{array}{l}\text { Khizanah al- } \\
\text { Hikmah: Jurnal } \\
\text { Ilmu Perpustakaan, } \\
\text { Informasi dan } \\
\text { Kearsipa }\end{array}$ & 2013 \\
\hline 5 & Sumarni Ria Ariyanti & \begin{tabular}{|l|} 
Preservasi Naskah Kuno \\
di Perpustakaan Rekso \\
Pustaka Surakarta sebagai \\
Upaya Penyelamatan \\
Aset Keraton Pura \\
Mangkunegaran \\
Surakarta
\end{tabular} & $\begin{array}{l}\text { Jurnal Ilmiah } \\
\text { Kepustakawanan } \\
\text { "Libraria" }\end{array}$ & 2017 \\
\hline 6 & $\begin{array}{l}\text { Sumarni dan } \\
\text { Lailatur Rahmi }\end{array}$ & $\begin{array}{l}\text { Perpustakaan Digital "Isu } \\
\text { Preservasi Digital" Alasan, } \\
\text { Proses dan Tantangan Ke } \\
\text { depan }\end{array}$ & $\begin{array}{l}\text { Shaut Al- } \\
\text { Maktabah: Jurnal } \\
\text { Perpustakaan, } \\
\text { Arsip dan } \\
\text { Dokumentasi }\end{array}$ & 2018 \\
\hline 7 & $\begin{array}{l}\text { Viola Dwi Putri } \\
\text { Syarif }\end{array}$ & $\begin{array}{l}\text { Peran pemerintah dalam } \\
\text { Menyelamatkan naskah } \\
\text { kuno Minangkabau pasca } \\
\text { gempa padang Untuk } \\
\text { pelestarian budaya } \\
\text { Masyarakat minangkabau }\end{array}$ & $\begin{array}{l}\text { Pustakaloka: Jurnal } \\
\text { Kajian Informasi } \\
\text { dan Perpustakaan }\end{array}$ & 2015 \\
\hline 8 & Tuty Hendrawati & $\begin{array}{l}\text { Digitalisasi Manuskrip } \\
\text { Nusantara Sebagai } \\
\text { Pelestari Intelektual } \\
\text { Leluhur Bangsa }\end{array}$ & Media Pustakawan & 2018 \\
\hline 9 & $\begin{array}{l}\text { Fadhila Nurul Husna } \\
\text { Zalmi }\end{array}$ & $\begin{array}{l}\text { Preservasi bahan pustaka } \\
\text { di perpustakaan Pusat } \\
\text { uin imam bonjol padang } \\
\text { (studi kasus kerusakan } \\
\text { bahan pustaka) }\end{array}$ & $\begin{array}{l}\text { Shaut Al- } \\
\text { Maktabah: Jurnal } \\
\text { Perpustakaan, } \\
\text { Arsip dan } \\
\text { Dokumentasi }\end{array}$ & 2019 \\
\hline 10 & Damaji Ratmono & $\begin{array}{l}\text { Tinjauan Pemanfaatan } \\
\text { Digital Printing dalam } \\
\text { Pelestarian Majalah } \\
\text { Terjilid Koleksi } \\
\text { Perpustakaan Nasional RI }\end{array}$ & Media Pustakawan & 2017 \\
\hline
\end{tabular}




\begin{tabular}{|c|c|c|c|c|}
\hline 11 & $\begin{array}{l}\text { Hijrana dan Taufiq } \\
\text { Mathar }\end{array}$ & $\begin{array}{l}\text { Upaya Pelestarian } \\
\text { Naskah Kuno Di Badan } \\
\text { Perpustakaan Dan Arsip } \\
\text { Daerah Provinsi Sulawesi } \\
\text { Selatan }\end{array}$ & \begin{tabular}{|l|} 
Khizanah Al- \\
Hikmah: Jurnal \\
Ilmu Perpustakaan, \\
Informasi dan \\
Kearsipan
\end{tabular} & 2015 \\
\hline 12 & $\begin{array}{l}\text { Noeraida, dan Andri } \\
\text { Sungkono }\end{array}$ & $\begin{array}{l}\text { Analisis Pemanfaatan } \\
\text { Repositori untuk } \\
\text { Preservasi Pengetahuan } \\
\text { Nuklir di BATAN }\end{array}$ & Media Pustakawan & 2019 \\
\hline 13 & Karina Okta Bella & $\begin{array}{l}\text { Peranan perpustakaan } \\
\text { dan museum tembakau } \\
\\
\text { Dalam pelestarian } \\
\text { kebudayaan kota jember }\end{array}$ & \begin{tabular}{|l|} 
BIBLIOTIKA: \\
Jurnal Kajian \\
Perpustakaan dan \\
Informasi
\end{tabular} & 2017 \\
\hline 14 & Yolan Priatna & $\begin{array}{l}\text { Melek Informasi Sebagai } \\
\text { Kunci Keberhasilan } \\
\text { Pelestarian Budaya Lokal }\end{array}$ & Jurnal PUBLIS & 2017 \\
\hline 15 & Indah Purwani & $\begin{array}{l}\text { Penentuan Skala Prioritas } \\
\text { Preservasi Upaya } \\
\text { Perlindungan Nilai } \\
\text { Informasi } \\
\text { Koleksi Di Perpustakaan } \\
\text { Nasional RI }\end{array}$ & Media Pustakawan & 2012 \\
\hline 16 & Purwono & $\begin{array}{l}\text { Pelestarian Jangka } \\
\text { Panjang Dan Aksesibilitas } \\
\text { Isi Informasi Dengan } \\
\text { Teknologi }\end{array}$ & Media Pustakawan & 2010 \\
\hline 17 & $\begin{array}{l}\text { Ratnawati } \\
\text { Nurwahyuningsih } \\
\text { dan Nita Ismayati }\end{array}$ & $\begin{array}{l}\text { Evaluasi kegiatan } \\
\text { preservasi fisik naskah } \\
\text { kuno Di perpustakaan } \\
\text { nasional RI menggunakan } \\
\text { model Cipp (context, } \\
\text { input, process, product) }\end{array}$ & $\begin{array}{l}\text { Bibliotech : Jurnal } \\
\text { Ilmu Perpustakaan } \\
\text { dan Informasi }\end{array}$ & 2019 \\
\hline 18 & $\begin{array}{l}\text { Muhammad Bu'ang, } \\
\text { Reni Anggraini, } \\
\text { Sabrina Tri } \\
\text { Ambarwati, } \\
\\
\text { dan Zahrotun } \\
\text { Fadhila }\end{array}$ & $\begin{array}{l}\text { Pelestarian bahan pustaka } \\
\text { di museum balaputera } \\
\text { dewa Sumatera Selatan }\end{array}$ & Jurnal lqra' & 2018 \\
\hline 19 & Musrifah & $\begin{array}{l}\text { Strategi Preservasi Digital } \\
\text { Di Perpustakaan UIN } \\
\text { Sunan Kalijaga Yogyakarta }\end{array}$ & \begin{tabular}{|l|} 
Khizanah Al- \\
Hikmah: Jurnal \\
Ilmu Perpustakaan, \\
Imformasi dan \\
Kearsipan
\end{tabular} & 2017 \\
\hline 19 & $\begin{array}{l}\text { Dimas Andika Putra, } \\
\text { Kusubakti Andajani } \\
\text { dan Zeni Istiqomah }\end{array}$ & $\begin{array}{l}\text { Implementasi Preservasi } \\
\text { Digital Koleksi Karya } \\
\text { IImiah di Perpustakaan } \\
\text { Maulana Malik Ibrahim } \\
\text { Malang }\end{array}$ & \begin{tabular}{|l|} 
BIBLIOTIKA \\
Jurnal Kajian \\
Perpustakaan dan \\
Informasi
\end{tabular} & 2017 \\
\hline 20 & $\begin{array}{l}\text { Fiendly Prastika, Ida } \\
\text { Lestari dan Taufiq } \\
\text { Kurniawan }\end{array}$ & $\begin{array}{l}\text { Konservasi Koleksi Lukisan } \\
\text { Pada Kelompok Kerja } \\
\text { Pelestarian Bahan Pustaka } \\
\text { Di UPT Perpustakaan } \\
\text { Proklamator Bung Karno } \\
\text { Blitar-Jawa Timur }\end{array}$ & \begin{tabular}{|l|} 
BIBLIOTIKA \\
Jurnal Kajian \\
Perpustakaan dan \\
Informasi
\end{tabular} & 2017 \\
\hline
\end{tabular}

\begin{tabular}{|c|c|c|c|c|}
\hline 21 & Hirma Susilawati & $\begin{array}{l}\text { Preservasi Naskah Budaya } \\
\text { Di Museum Sonobudoyo }\end{array}$ & $\begin{array}{l}\text { Al Maktabah: } \\
\text { Jurnal Kajian Ilmu } \\
\text { dan Perpustakaan }\end{array}$ & 2016 \\
\hline 22 & $\begin{array}{l}\text { Ana } \\
\text { Irhandayaningsih }\end{array}$ & \begin{tabular}{|l|} 
Pelestarian Kesenian \\
Tradisional sebagai Upaya \\
Dalam \\
\\
Menumbuhkan \\
Kecintaan Budaya Lokal \\
di Masyarakat Jurang \\
Blimbing Tembalang
\end{tabular} & $\begin{array}{l}\text { ANUVA: Jurnal } \\
\text { Kajian Budaya, } \\
\text { Perpustakaan dan } \\
\text { Informasi }\end{array}$ & 2018 \\
\hline 23 & Dwi Fajar Saputra & \begin{tabular}{|l} 
Preservasi Konten Lokal di \\
Perpustakaan Perguruan \\
Tinggi \\
\\
(Studi Kasus Medical \\
Knowledge Center UPN \\
Veteran Jakarta)
\end{tabular} & $\begin{array}{l}\text { PUSTABIBLIA: } \\
\text { Journal of Library } \\
\text { and Information } \\
\text { Science }\end{array}$ & 2019 \\
\hline 24 & $\begin{array}{l}\text { Nurrohmah Hidayah } \\
\text { dan Arina Faila } \\
\text { Saufa }\end{array}$ & \begin{tabular}{|l|} 
Preservasi Digital Arsip \\
Naskah Kuno: Studi Kasus \\
Preservasi Arsip di Badan \\
Arsip dan Perpustakaan \\
Provinsi Jawa Tengah
\end{tabular} & $\begin{array}{l}\text { JIPI (Jurnal IImu } \\
\text { Perpustakaan dan } \\
\text { Informasi) }\end{array}$ & 2019 \\
\hline 25 & Sahidi & $\begin{array}{l}\text { Pentingnya pelestarian } \\
\text { naskah kuno sebagai } \\
\text { warisan budaya bangsa }\end{array}$ & Jurnal lqra' & 2018 \\
\hline 26 & Ragil Tri Atmi & \begin{tabular}{|l|} 
Evaluasi Workshop Badan \\
Arsip dan Perpustakaan \\
Jawa Timur sebagai \\
\\
Bentuk Knowldge \\
Sharing dari Kebijakan \\
Preservasi Lokal \\
Jatimuran
\end{tabular} & $\begin{array}{l}\text { RECORD AND } \\
\text { LIBRARY } \\
\text { JOURNAL }\end{array}$ & 2015 \\
\hline 27 & $\begin{array}{l}\text { Sintha Ratnawati } \\
\text { dan Yuli Rahmawati }\end{array}$ & $\begin{array}{l}\text { Preservasi Digital Foto } \\
\text { Jurnalistik: Studi Kasus di } \\
\text { Kompas Daily }\end{array}$ & $\begin{array}{l}\text { RECORD AND } \\
\text { LIBRARY } \\
\text { JOURNAL }\end{array}$ & 2015 \\
\hline 28 & $\begin{array}{l}\text { Sukaesih, Yunus } \\
\text { Winoto, Agus } \\
\text { Rusmana, Nuning } \\
\text { Kurniasih }\end{array}$ & \begin{tabular}{|l|} 
Preservasi Naskah \\
Kuno sebagai Upaya \\
Pembangunan Knowledge \\
\\
Management: (Studi \\
Kegiatan Preservasi \\
Naskah Kuno oleh \\
Masyarakat \\
sebagai Upaya \\
Pembagunan Knowledge \\
Management)
\end{tabular} & $\begin{array}{l}\text { RECORD AND } \\
\text { LIBRARY } \\
\text { JOURNAL }\end{array}$ & 2016 \\
\hline 29 & $\begin{array}{l}\text { Saleha Rodiah, Ute } \\
\text { Lies Siti Khadijah, } \\
\text { Nuning Kurniasih }\end{array}$ & $\begin{array}{l}\text { Naskah Kuno sebagai } \\
\text { Identitas Budaya di } \\
\text { Masyarakat Kabuyutan } \\
\text { Ciburuy Bayongbong } \\
\text { Kabupaten Garut }\end{array}$ & $\begin{array}{l}\text { RECORD AND } \\
\text { LIBRARY } \\
\text { JOURNAL }\end{array}$ & 2017 \\
\hline 30 & $\begin{array}{l}\text { Agus Rumsana, } \\
\text { Edwin Rizal dan Ute } \\
\text { Lies Siti Khadijah }\end{array}$ & $\begin{array}{l}\text { Literasi Sosial Budaya } \\
\text { Masyarakat Penyangga } \\
\text { Hutan Terhadap } \\
\text { Pelestarian } \\
\\
\text { Taman Nasional Gunung } \\
\text { Gede Halimun Salak } \\
\text { (TNGHS) }\end{array}$ & $\begin{array}{l}\text { RECORD AND } \\
\text { LIBRARY } \\
\text { JOURNAL }\end{array}$ & 2017 \\
\hline
\end{tabular}




\begin{tabular}{|c|c|c|c|c|}
\hline 31 & \begin{tabular}{|l|} 
Fauzan \\
Hidayatullah, Wahid \\
Nashihuddin, Kadek \\
Aryana Dwi Putra
\end{tabular} & $\begin{array}{|lr|}\text { Kegiatan } & \text { Pelestarian dan } \\
\text { Promosi } & \text { Candi Kimpulan } \\
\text { di Area } & \text { Perpustakaan } \\
\text { Universitas } & \text { Islam } \\
\text { Indonesia } & \end{array}$ & $\begin{array}{l}\text { ANUVA: Jurnal } \\
\text { Kajian Budaya, } \\
\text { Perpustakaan dan } \\
\text { Informasi }\end{array}$ & 2020 \\
\hline 32 & $\begin{array}{l}\text { Nurul Fikriati } \\
\text { Ayu Hapsari dan } \\
\text { Catharina Labore } \\
\text { Tatiek Ariyani }\end{array}$ & $\begin{array}{l}\text { Urgensi Preservasi Arsip } \\
\text { Digital }\end{array}$ & $\begin{array}{l}\text { RECORD AND } \\
\text { LIBRARY } \\
\text { JOURNAL }\end{array}$ & 2018 \\
\hline 33 & Lydia Christiani & $\begin{array}{l}\text { Preservasi, Konservasi dan } \\
\text { Restorasi Dokumen di } \\
\text { Rekso Pustaka }\end{array}$ & $\begin{array}{l}\text { ANUVA: Jurnal } \\
\text { Kajian Budaya, } \\
\text { Perpustakaan dan } \\
\text { Informasi }\end{array}$ & 2020 \\
\hline 34 & $\begin{array}{l}\text { Nani Adeliny, Ninis } \\
\text { Agustini Damayanti, } \\
\text { Ute Lies Siti } \\
\text { Khadijah }\end{array}$ & $\begin{array}{l}\text { Kegiatan Pelestarian } \\
\text { Bahan Pustaka Pasca } \\
\text { Gempa di Badan } \\
\text { Perpustakaan dan } \\
\text { Kearsipan Provinsi } \\
\text { Sumatera Barat }\end{array}$ & $\begin{array}{l}\text { JURNAL KAJIAN } \\
\text { INFORMASI \& } \\
\text { PERPUSTAKAAN }\end{array}$ & 2013 \\
\hline 35 & $\begin{array}{l}\text { I Nyoman Sedana, } \\
\text { Ninis Agustini } \\
\text { Damayanti dan Ute } \\
\text { Lies Siti Khadijah }\end{array}$ & \begin{tabular}{|l|} 
Preservasi Berbasis \\
Kearifan Lokal \\
(Studi Kasus Mengenai \\
Preservasi Preventif dan \\
Kuratif \\
Manuskrip Lontar Sebagai \\
Warisan Budaya di \\
Kabupaten \\
Klungkung Bali)
\end{tabular} & $\begin{array}{l}\text { JURNAL KAJIAN } \\
\text { INFORMASI \& } \\
\text { PERPUSTAKAAN }\end{array}$ & 2013 \\
\hline 36 & $\begin{array}{l}\text { Santi Susanti, } \\
\text { Deddy Mulyana, } \\
\text { Ninis Agustini } \\
\text { Damayani }\end{array}$ & $\begin{array}{l}\text { Penulis Sunda Sebagai } \\
\text { Pelestari Budaya }\end{array}$ & \begin{tabular}{|l} 
Jurnal Kajian \\
Informasi \& \\
Perpustakaan
\end{tabular} & 2013 \\
\hline 37 & $\begin{array}{l}\text { Eka Dian } \\
\text { Oktaningrum, dan } \\
\text { Fitri Perdana }\end{array}$ & $\begin{array}{l}\text { Preservasi koleksi bahan } \\
\text { pustaka akibat bencana } \\
\text { alam Di perpustakaan } \\
\text { SDN Kudang Tasikmalaya }\end{array}$ & $\begin{array}{l}\text { JURNAL KAJIAN } \\
\text { INFORMASI \& } \\
\text { PERPUSTAKAAN }\end{array}$ & 2017 \\
\hline 38 & Desriyeni & $\begin{array}{l}\text { Partisipasi Masyarakat } \\
\text { dalam Upaya Pelestarian } \\
\text { Naskah Kuno } \\
\text { Minangkabau di Nagari } \\
\text { Koto Padang } \\
\text { Kabupaten Dharmasraya } \\
\text { Sumatera Barat }\end{array}$ & $\begin{array}{l}\text { Record and Library } \\
\text { Journal }\end{array}$ & 2018 \\
\hline 39 & Yona Primadesi & $\begin{array}{l}\text { Preservasi Pengetahuan } \\
\text { dalam Tradisi Lisan Seni } \\
\text { Pertunjukan Randai di } \\
\text { Minangkabau Sumatera } \\
\text { Barat }\end{array}$ & $\begin{array}{l}\text { JURNAL KAJIAN } \\
\text { INFORMASI \& } \\
\text { PERPUSTAKAAN }\end{array}$ & 2013 \\
\hline 40 & Septa dan Heriyanto & $\begin{array}{l}\text { Pengelolaan Dokumen } \\
\text { Tradisi Lisan Gaok } \\
\text { sebagai Wujud } \\
\text { Pelestarian Budaya } \\
\text { di Perpustakaan }\end{array}$ & $\begin{array}{l}\text { Record and Library } \\
\text { Journal }\end{array}$ & 2020 \\
\hline
\end{tabular}

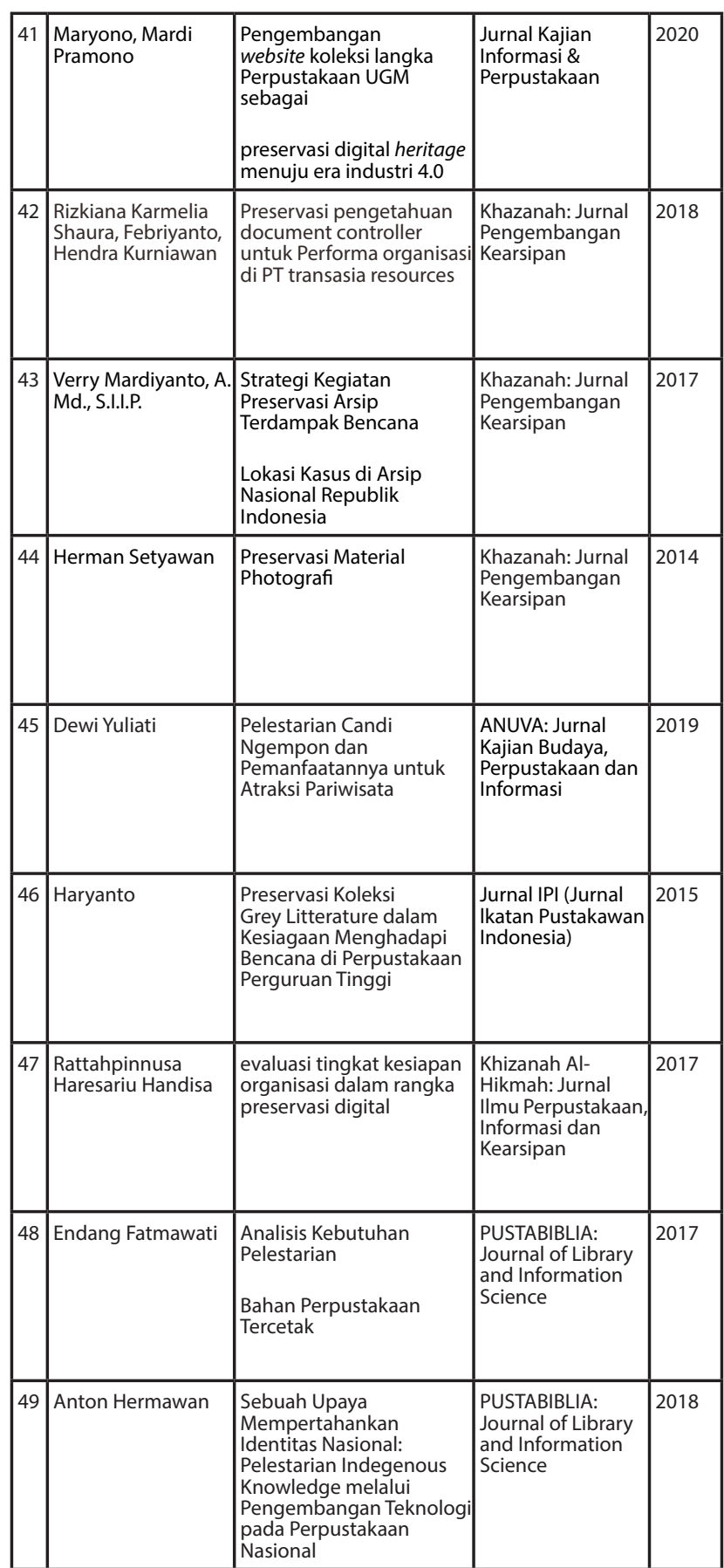

Berdasarkan Tabel 2 di atas, dapat diketahui kajian preservasi di Indonesia diterbitkan dalam jurnal-jurnal sains informasi dan kepustakaan terakreditasi sinta dimulai dari tahun 2010-2020. Seperti tertetera pada tabel 3. 
Tabel.3 Jumlah Kajian Preservasi Terbit Setiap Tahun Di Jurnal Sains Informasi Dan Kepustakaan Terakreditasi Sinta

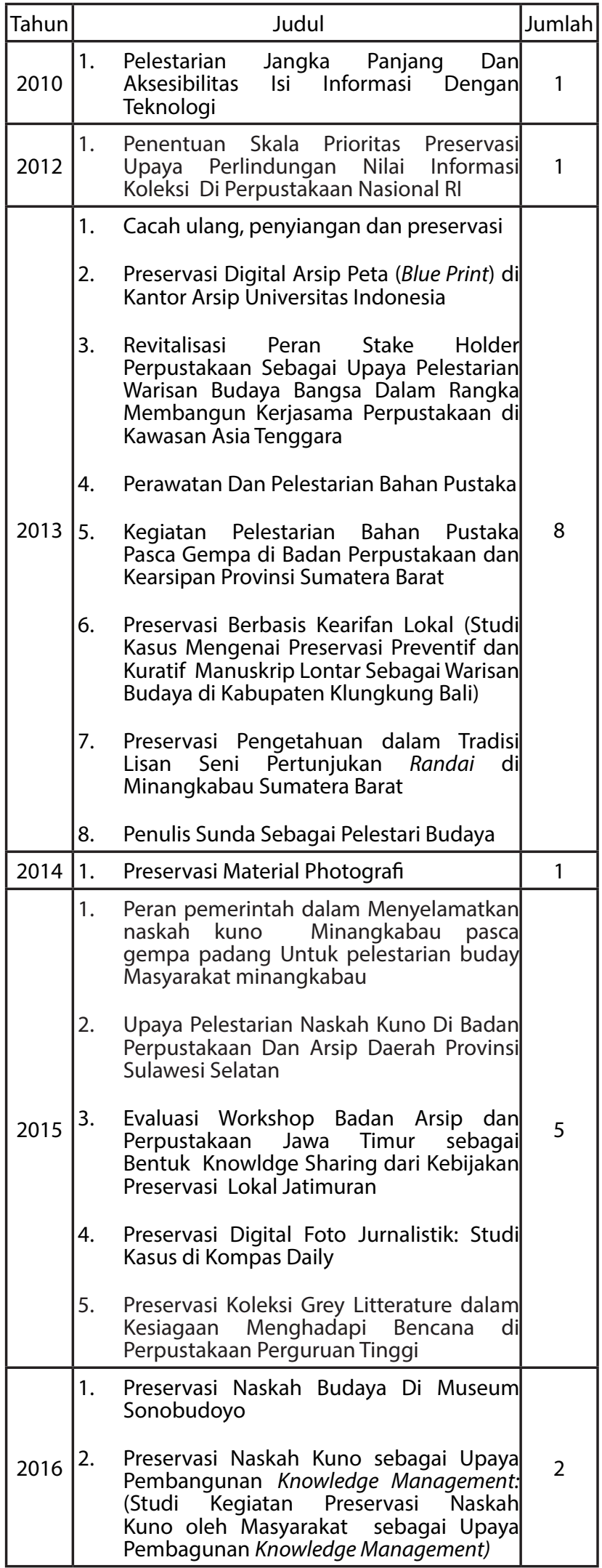

1. Preservasi Naskah Kuno di Perpustakaan Rekso Pustaka Surakarta sebagai Upaya Penyelamatan Aset Keraton Pura Mangkunegaran Surakarta

2. Tinjauan Pemanfaatan Digital Printing dalam Pelestarian Majalah Terjilid Koleksi Perpustakaan Nasional RI

3. Peranan perpustakaan dan museum tembakau Dalam pelestarian kebudayaan kota jember

4. Melek Informasi Sebagai Kunci Keberhasilan Pelestarian Budaya Lokal

5. Strategi Preservasi Digital Di Perpustakaan UIN Sunan Kalijaga Yogyakarta

6. Implementasi Preservasi Digital Koleksi Karya Ilmiah di Perpustakaan Maulana Malik Ibrahim Malang

7. Konservasi Koleksi Lukisan Pada Kelompok Kerja Pelestarian Bahan Pustaka Di UPT Perpustakaan Proklamator Bung Karno Blitar-Jawa Timur

8. Naskah Kuno sebagai Identitas Budaya di Masyarakat Kabuyutan Ciburuy Bayongbong Kabupaten Garut

9. Literasi Sosial Budaya Masyarakat Penyangga Hutan Terhadap Pelestarian Taman Nasional Gunung Gede Halimun Salak (TNGHS)

10. Preservasi koleksi bahan pustaka akibat bencana alam Di perpustakaan SDN Kudang Tasikmalaya

11. Strategi Kegiatan Preservasi Arsip Terdampak Bencana Lokasi Kasus di Arsip Nasional Republik Indonesia

12. evaluasi tingkat kesiapan organisasi dalam rangka preservasi digital

13. Analisis Kebutuhan Pelestarian Bahan Perpustakaan Tercetak 


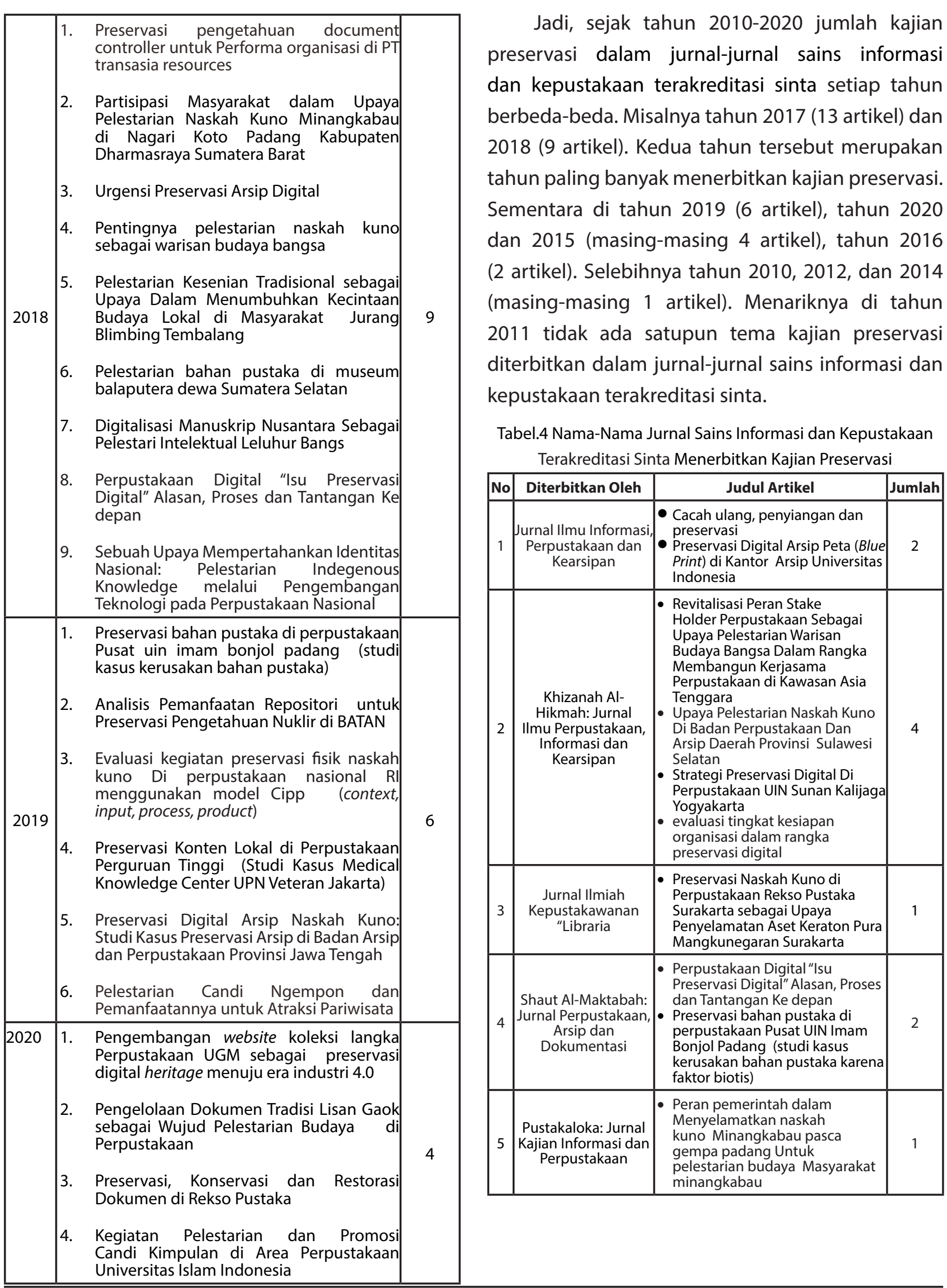




\begin{tabular}{|c|c|c|c|}
\hline 6 & Media Pustakawan & $\begin{array}{l}\text { - Digitalisasi Manuskrip Nusantara } \\
\text { Sebagai Pelestari Intelektual } \\
\text { Leluhur Bangsa } \\
\text { - Tinjauan Pemanfaatan Digital } \\
\text { Printing dalam Pelestarian } \\
\text { Majalah Terjilid Koleksi } \\
\text { Perpustakaan Nasional RI } \\
\text { - Analisis Pemanfaatan Repositori } \\
\text { untuk Preservasi Pengetahuan } \\
\text { Nuklir di BATAN Penentuan } \\
\text { Skala Prioritas Preservasi Upaya } \\
\text { Perlindungan Nilai Informasi } \\
\text { Koleksi Di Perpustakaan } \\
\text { Nasional RI } \\
\text { - Pelestarian Jangka Panjang } \\
\text { Dan Aksesibilitas Isi Informasi } \\
\text { Dengan Teknologi }\end{array}$ & 4 \\
\hline 7 & $\begin{array}{l}\text { BIBLIOTIKA: Jurnal } \\
\text { Kajian Perpustakaan } \\
\text { dan Informasi }\end{array}$ & $\begin{array}{l}\text { - Peranan perpustakaan dan } \\
\text { museum tembakau Dalam } \\
\text { pelestarian kebudayaan kota } \\
\text { jember } \\
\text { - Implementasi Preservasi } \\
\text { Digital Koleksi Karya Ilmiah di } \\
\text { Perpustakaan Maulana Malik } \\
\text { Ibrahim Malang } \\
\text { - Konservasi Koleksi Lukisan Pada } \\
\text { Kelompok Kerja Pelestarian } \\
\text { Bahan Pustaka Di UPT } \\
\text { Perpustakaan Proklamator Bung } \\
\text { Karno Blitar-Jawa Timur }\end{array}$ & 3 \\
\hline 8 & Jurnal PUBLIS & $\begin{array}{l}\text { - Melek Informasi Sebagai Kunci } \\
\text { Keberhasilan Pelestarian Budaya } \\
\text { Lokal }\end{array}$ & 1 \\
\hline 9 & $\begin{array}{l}\text { Bibliotech : Jurnal } \\
\text { Ilmu Perpustakaan } \\
\text { dan Informasi }\end{array}$ & $\begin{array}{l}\text { Evaluasi kegiatan preservasi fisik } \\
\text { naskah kuno Di perpustakaan } \\
\text { nasional RI menggunakan model } \\
\text { Cipp (context, input, process, } \\
\text { product) }\end{array}$ & 1 \\
\hline 10 & Jurnal lqra' & $\begin{array}{l}\text { - Pelestarian bahan pustaka } \\
\text { di museum balaputera dewa } \\
\text { Sumatera Selatan } \\
\text { - Pentingnya pelestarian naskah } \\
\text { kuno sebagai warisan budaya } \\
\text { bangsa }\end{array}$ & 2 \\
\hline 11 & $\begin{array}{l}\text { Al Maktabah : Jurnal } \\
\text { Kajian Ilmu dan } \\
\text { Perpustakaan }\end{array}$ & $\begin{array}{l}\text { - Preservasi Naskah Budaya Di } \\
\text { Museum Sonobudoyo }\end{array}$ & 1 \\
\hline 12 & $\begin{array}{l}\text { ANUVA: Jurnal } \\
\text { Kajian Budaya, } \\
\text { Perpustakaan dan } \\
\text { Informasi }\end{array}$ & $\begin{array}{l}\text { - Pelestarian Kesenian Tradisional } \\
\text { sebagai Upaya Dalam } \\
\text { Menumbuhkan Kecintaan } \\
\text { Budaya Lokal di Masyarakat } \\
\text { Jurang Blimbing Tembalang } \\
\text { - Kegiatan Pelestarian dan } \\
\text { Promosi Candi Kimpulan di Area } \\
\text { Perpustakaan Universitas Islam } \\
\text { Indonesia } \\
\text { - Preservasi, Konservasi dan } \\
\text { Restorasi Dokumen di Rekso } \\
\text { Pustaka } \\
\text { - Pelestarian Candi Ngempon dan } \\
\text { Pemanfaatannya untuk Atraksi } \\
\text { Pariwisata }\end{array}$ & 4 \\
\hline 13 & $\begin{array}{l}\text { PUSTABIBLIA: Journal } \\
\text { of Library and } \\
\text { Information Science }\end{array}$ & \begin{tabular}{|l|} 
- Preservasi Konten Lokal di \\
Perpustakaan Perguruan Tinggi \\
(Studi Kasus Medical Knowledge \\
Center UPN Veteran Jakarta) \\
- Analisis Kebutuhan Pelestarian \\
Bahan Perpustakaan Tercetak \\
- Sebuah Upaya Mempertahankan \\
Identitas Nasional: Pelestarian \\
Indegenous Knowledge melalui \\
Pengembangan Teknologi pada \\
Perpustakaan Nasional
\end{tabular} & 3 \\
\hline
\end{tabular}

\begin{tabular}{|c|c|c|c|}
\hline 14 & $\begin{array}{l}\text { JIPI (Jurnal IImu } \\
\text { Perpustakaan dan } \\
\text { Informasi) }\end{array}$ & $\begin{array}{l}\text { - Preservasi Digital Arsip Naskah } \\
\text { Kuno: Studi Kasus Preservasi } \\
\text { Arsip di Badan Arsip dan } \\
\text { Perpustakaan Provinsi Jawa } \\
\text { Tengah }\end{array}$ & 1 \\
\hline 15 & $\begin{array}{l}\text { RECORD AND } \\
\text { LIBRARY } \\
\text { JOURNAL }\end{array}$ & $\begin{array}{l}\text { - Evaluasi Workshop Badan Arsip } \\
\text { dan Perpustakaan Jawa Timur } \\
\text { sebagai Bentuk Knowldge } \\
\text { Sharing dari Kebijakan Preservasi } \\
\text { Lokal Jatimuran } \\
\text { - Preservasi Digital Foto } \\
\text { Jurnalistik: Studi Kasus di } \\
\text { Kompas Daily } \\
\text { - Preservasi Naskah Kuno sebagai } \\
\text { Upaya Pembangunan Knowledge } \\
\text { Management: (Studi Kegiatan } \\
\text { Preservasi Naskah Kuno oleh } \\
\text { Masyarakat sebagai Upaya } \\
\text { Pembagunan Knowledge } \\
\text { Management) } \\
\text { - Naskah Kuno sebagai Identitas } \\
\text { Budaya di Masyarakat Kabuyutan } \\
\text { Ciburuy Bayongbong Kabupaten } \\
\text { Garut } \\
\text { - Literasi Sosial Budaya } \\
\text { Masyarakat Penyangga Hutan } \\
\text { Terhadap Pelestarian Taman } \\
\text { Nasional Gunung Gede Halimun } \\
\text { Salak (TNGHS) } \\
\text { - Urgensi Preservasi Arsip Digital } \\
\text { - Partisipasi Masyarakat dalam } \\
\text { Upaya Pelestarian Naskah Kuno } \\
\text { Minangkabau di Nagari Koto } \\
\text { Padang Kabupaten Dharmasraya } \\
\text { Tradisi Lisan Gaok sebagai } \\
\text { Wujud Pelestarian Budaya di } \\
\text { Perpustakaan }\end{array}$ & 8 \\
\hline 16 & $\begin{array}{l}\text { JURNAL KAJIAN } \\
\text { INFORMASI \& } \\
\text { PERPUSTAKAAN }\end{array}$ & $\begin{array}{l}\text { - Kegiatan Pelestarian Bahan } \\
\text { Pustaka Pasca Gempa di Badan } \\
\text { Perpustakaan dan Kearsipan } \\
\text { Provinsi Sumatera Barat } \\
\text { - Preservasi Berbasis Kearifan } \\
\text { Lokal (Studi Kasus Mengenai } \\
\text { Preservasi Preventif dan Kuratif } \\
\text { Manuskrip Lontar Sebagai } \\
\text { Warisan Budaya di Kabupaten } \\
\text { Klungkung Bali) } \\
\text { - Penulis Sunda Sebagai Pelestari } \\
\text { Budaya } \\
\text { - Preservasi koleksi bahan } \\
\text { pustaka akibat bencana alam } \\
\text { Di perpustakaan SDN Kudang } \\
\text { Tasikmalaya } \\
\text { - Preservasi Pengetahuan dalam } \\
\text { Tradisi Lisan Seni Pertunjukan } \\
\text { Randai di Minangkabau } \\
\text { Sumatera Barat } \\
\text { - Pengembangan website koleksi } \\
\text { langka Perpustakaan UGM } \\
\text { sebagai preservasi digital } \\
\text { heritage menuju era industri } 4.0\end{array}$ & 6 \\
\hline 17 & $\begin{array}{l}\text { Khazanah: Jurnal } \\
\text { Pengembangan } \\
\text { Kearsipan }\end{array}$ & $\begin{array}{l}\text { - Preservasi pengetahuan } \\
\text { document controller untuk } \\
\text { Performa organisasi di PT } \\
\text { transasia resources } \\
\text { - Strategi Kegiatan Preservasi } \\
\text { Arsip Terdampak Bencana Lokasi } \\
\text { Kasus di Arsip Nasional Republik } \\
\text { Indonesia } \\
\text { - Preservasi Material Photografi }\end{array}$ & 3 \\
\hline 18 & $\begin{array}{l}\text { Jurnal IPI (Ikatan } \\
\text { Pustakawan } \\
\text { Indonesia) }\end{array}$ & $\begin{array}{l}\text { - Preservasi Koleksi Grey } \\
\text { Litterature dalam Kesiagaan } \\
\text { Menghadapi Bencana di } \\
\text { Perpustakaan Perguruan Tinggi }\end{array}$ & 1 \\
\hline
\end{tabular}


Daridua puluh limajurnal-jurnal sains informasi dan kepustakaan terakreditasi sinta, tidak semua jurnal-jurnal tersebut menerbitkan tema preservasi ataupun pelestarian. Misalnya jurnal (1) Berkala IImu Perpustakaan dan informasi-UGM, (2) Baca: Jurnal Dokumentasi dan Informasi-Lembaga IImu Pengetahuan Indonesia, (3) Journal of Documentation and Information Science-Ikatan Sarjana IImu Perpustakaan dan Informasi Indonesia, (4) Jurnal Pustaka Budaya-Universitas Lancang Kuning, dan (5) Edulib: Journal of Library and Information ScienceUniversitas Pendidikan Indonesia, dan (6) Lentera Pustaka: Jurnal Kajian IImu Perpustakaan, Informasi dan Kearsipan- Universitas Dipenogoro. Ada satu kajian preservasi atau pelestarian diterbitkan jurnal Diplomatika: Jurnal Kearsipan Terapan (UGM) tidak bisa ditemui artikel lengkapnya.

Berbeda dengan kedelapan belas jurnaljurnal lainnya, masing-masing menerbitkan tema preservasi ataupun pelestarian dan paling banyak mempublikasikan tema preservasi ialah jurnal Record and Library Journal (8 artikel), Jurnal Kajian Informasi \& Perpustakaan (6 artikel), Media Pustakawan dan Khizanah Al-Hikmah: Jurnal IImu Perpustakaan, Informasi dan Kearsipan (4 artikel). Akan tetapi, kedelapan belas jurnal-jurnal tersebut mempublikasikan judul kajian preservasi atau pelestarian beragam-ragam. Untuk lebih jelasnya tersaji dalam tabel 5 berikut.
Tabel.5 Klasifikasi Judul Kajian Preservasi Di Indonesia pada Jurnal Sains Informasi dan Kepustakaan Terakreditasi Sinta

\begin{tabular}{|c|c|}
\hline & $\begin{array}{l}\text { 1. Upaya Pelestarian Naskah Kuno Di Badan } \\
\text { Perpustakaan Dan Arsip Daerah Provinsi } \\
\text { Sulawesi Selatan } \\
\text { 2. Preservasi Naskah Kuno di Perpustakaan } \\
\text { Rekso Pustaka Surakarta sebagai } \\
\text { Upaya Penyelamatan Aset Keraton Pura } \\
\text { Mangkunegaran Surakarta } \\
\text { 3. Peran pemerintah dalam Menyelamatkan } \\
\text { naskah kuno Minangkabau pasca gempa } \\
\text { padang Untuk pelestarian budaya } \\
\text { Masyarakat minangkabau } \\
\text { 4. Digitalisasi Manuskrip Nusantara Sebagai } \\
\text { Pelestari Intelektual Leluhur Bangsa } \\
\text { 5. Evaluasi kegiatan preservasi fisik naskah } \\
\text { kuno Di perpustakaan nasional RI } \\
\text { menggunakan model Cipp (context, input, } \\
\text { process, product) } \\
\text { 6. Pentingnya pelestarian naskah kuno } \\
\text { sebagai warisan budaya bangsa } \\
\text { 7. Preservasi Naskah Budaya Di Museum } \\
\text { Sonobudoyo } \\
\text { 8. Preservasi Digital Arsip Naskah Kuno: Studi } \\
\text { Kasus Preservasi Arsip di Badan Arsip dan } \\
\text { Perpustakaan Provinsi Jawa Tengah } \\
\text { 9. Preservasi Naskah Kuno sebagai Upaya } \\
\text { Pembangunan Knowledge Management: } \\
\text { (Studi Kegiatan Preservasi Naskah } \\
\text { Kuno oleh Masyarakat sebagai Upaya } \\
\text { Pembagunan Knowledge Management) } \\
\text { 10. Naskah Kuno sebagai Identitas } \\
\text { Budaya di Masyarakat Kabuyutan Ciburuy } \\
\text { Bayongbong Kabupaten Garut } \\
\text { 11. Partisipasi Masyarakat dalam Upaya } \\
\text { Pelestarian Naskah Kuno Minangkabau } \\
\text { di Nagari Koto Padang Kabupaten } \\
\text { Dharmasraya Sumatera Barat } \\
\text { 12. Preservasi Berbasis Kearifan Lokal } \\
\text { (Studi Kasus Mengenai Preservasi Preventif } \\
\text { dan Kuratif Manuskrip Lontar Sebagai } \\
\text { Warisan Budaya di Kabupaten Klungkung } \\
\text { Bali) }\end{array}$ \\
\hline
\end{tabular}




\begin{tabular}{|c|c|}
\hline $\begin{array}{l}\text { Pelestarian } \\
\text { Budaya }\end{array}$ & $\begin{array}{l}\text { 1. Revitalisasi Peran Stake Holder } \\
\text { Perpustakaan Sebagai Upaya Pelestarian } \\
\text { Warisan Budaya Bangsa Dalam Rangka } \\
\text { Membangun Kerjasama Perpustakaan di } \\
\text { Kawasan Asia Tenggara } \\
\text { 2. Peranan perpustakaan dan museum } \\
\text { tembakau Dalam pelestarian kebudayaan } \\
\text { kota jember } \\
\text { 3. Melek Informasi Sebagai Kunci Keberhasilan } \\
\text { Pelestarian Budaya Lokal } \\
\text { 4. Pelestarian Kesenian Tradisional sebagai } \\
\text { Upaya Dalam Menumbuhkan Kecintaan } \\
\text { Budaya Lokal di Masyarakat Jurang } \\
\text { Blimbing Tembalang } \\
\text { 5. Kegiatan Pelestarian dan Promosi Candi } \\
\text { Kimpulan di Area Perpustakaan Universitas } \\
\text { Islam Indonesia } \\
\text { 6. Literasi Sosial Budaya Masyarakat } \\
\text { Penyangga Hutan Terhadap Pelestarian } \\
\text { Taman Nasional Gunung Gede Halimun } \\
\text { Salak (TNGHS) } \\
\text { 7. Pengelolaan Dokumen Tradisi Lisan Gaok } \\
\text { sebagai Wujud Pelestarian Budaya di } \\
\text { Perpustakaan } \\
\text { 8. Penulis Sunda Sebagai Pelestari Budaya } \\
\text { 9. Evaluasi Workshop Badan Arsip dan } \\
\text { Perpustakaan Jawa Timur sebagai Bentuk } \\
\text { Knowldge Sharing dari Kebijakan Preservasi } \\
\text { Lokal Jatimuran } \\
\text { 10. Preservasi Konten Lokal di } \\
\text { Perpustakaan Perguruan Tinggi (Studi } \\
\text { Kasus Medical Knowledge Center UPN } \\
\text { Veteran Jakarta) } \\
\text { 11. Pelestarian Candi Ngempon dan } \\
\text { Pemanfaatannya untuk Atraksi Pariwisata }\end{array}$ \\
\hline $\begin{array}{l}\text { Preservasi } \\
\text { Arsip }\end{array}$ & $\begin{array}{l}\text { 1. Preservasi Digital Arsip Peta (Blue Print) di } \\
\text { Kantor Arsip Universitas Indonesia } \\
\text { 2. Strategi Kegiatan Preservasi Arsip } \\
\text { Terdampak Bencana Lokasi Kasus di Arsip } \\
\text { Nasional Republik Indonesia }\end{array}$ \\
\hline $\begin{array}{l}\text { Preservasi } \\
\text { bahan } \\
\text { pustaka }\end{array}$ & $\begin{array}{l}\text { 1. Preservasi bahan pustaka di perpustakaan } \\
\text { Pusat UIN Imam Bonjol Padang (studi kasus } \\
\text { kerusakan bahan pustaka) } \\
\text { 2. Pelestarian bahan pustaka di Museum } \\
\text { Balaputera dewa Sumatera Selatan } \\
\text { 3. Kegiatan Pelestarian Bahan Pustaka } \\
\text { Pasca Gempa di Badan Perpustakaan dan } \\
\text { Kearsipan Provinsi Sumatera Barat } \\
\text { 4. Preservasi koleksi bahan pustaka akibat } \\
\text { bencana alam Di perpustakaan SDN } \\
\text { Kudang Tasikmalaya } \\
\text { 5. Konservasi Koleksi Lukisan Pada Kelompok } \\
\text { Kerja Pelestarian Bahan Pustaka Di UPT } \\
\text { Perpustakaan Proklamator Bung Karno } \\
\text { Blitar-Jawa Timur } \\
\text { 6. Preservasi Koleksi Grey Litterature dalam } \\
\text { Kesiagaan Menghadapi Bencana di } \\
\text { Perpustakaan Perguruan Tinggi } \\
\text { 7. Analisis Kebutuhan Pelestarian Bahan } \\
\text { Perpustakaan Tercetak }\end{array}$ \\
\hline
\end{tabular}

\begin{tabular}{|l|l|}
\hline $\begin{array}{l}\text { Pelestarian } \\
\text { pengetahu- } \\
\text { an dan } \\
\text { informasi }\end{array}$ & $\begin{array}{l}\text { 1. Analisis Pemanfaatan Repositori untuk } \\
\text { Preservasi Pengetahuan Nuklir di BATAN } \\
\text { Penentuan Skala Prioritas Preservasi Upaya } \\
\text { Perlindungan Nilai Informasi Koleksi Di } \\
\text { Perpustakaan Nasional RI } \\
\text { 2. Pelestarian Jangka Panjang Dan } \\
\text { Aksesibilitas Isi Informasi Dengan Teknologi } \\
\text { 3. Preservasi Pengetahuan dalam Tradisi Lisan } \\
\text { Seni Pertunjukan Randai di Minangkabau } \\
\text { Sumatera Barat }\end{array}$ \\
\hline $\begin{array}{l}\text { 4. Sebuah Upaya Mempertahankan Identitas } \\
\text { Nasional: Pelestarian Indegenous } \\
\text { Knowledge melalui Pengembangan } \\
\text { Teknologi pada Perpustakaan Nasional }\end{array}$ \\
\hline photo & $\begin{array}{l}\text { 1. Preservasi Digital Foto Jurnalistik: Studi } \\
\text { Kasus di Kompas Daily }\end{array}$ \\
\hline 2. Preservasi Material Photografi
\end{tabular}

Jadi, berdasarkan judul kajian preservasi di indonesia pada jurnal-jurnal Sains Informasi dan Kepustakaan Terakreditasi Sinta, maka terdapat 10 topik kajian antara lain: (1) Pelestarian Naskah Kuno atau manuskrip, (2) Pelestarian Budaya, (3) Preservasi Arsip, (4) Preservasi bahan pustaka, (5) Pelestarian pengetahuan dan informasi, (6) Preservasi photo, (7) Preservasi Dokumen, (8) Preservasi Majalah, (9) Preservasi Digital, dan (10) Konsep Preservasi. Dari keseluruh topik paling dominan dibahas yaitu preservasi naskah kuno (10 artikel ) dan budaya (11 artikel). Sementara topik presevasi minim diulas yaitu konsep preservasi secara umum (1 artikel). 


\section{PENUTUP}

\section{Simpulan}

Dapat disimpulkan bahwa masih sedikit kajian preservasi yang diterbitkan pada jurnal-jurnal sains informasi dan kepustakaan berakreditasi SINTA. Kajian preservasi di Indonesia sudah memiliki keberagaman topik kajian. Dari keseluruhan jurnal sains informasi dan kepustakaan yang terakreditasi sinta, tidak semua jurnal tersebut mempublishkan tema tentang preservasi ataupun pelestarian. Seperti jurnal (1) Berkala Ilmu Perpustakaan dan informasi-UGM, (2) Baca: Jurnal Dokumentasi dan Informasi-Lembaga Ilmu Pengetahuan Indonesia, (3) Journal of Documentation and Information Science-Ikatan Sarjana IImu Perpustakaan dan Informasi Indonesia, (4) Jurnal IPI (Ikatan Pustakawan Indonesia)-Ikatan Pustakawan Indonesia (IPI) Pusat, (5) Jurnal Pustaka Budaya-Universitas Lancang Kuning, dan (6) Edulib : Journal of Library and Information Science- Universitas Pendidikan Indonesia, dan (7) Lentera Pustaka: Jurnal Kajian Ilmu Perpustakaan, Informasi dan Kearsipan- Universitas Dipenogoro.

\section{DAFTAR PUSTAKA}

Adeliny, N., 2012. Kegiatan Pelestarian Bahan Pustaka Pasca Gempa di Badan Perpustakaan dan Kearsipan Provinsi Sumatera Barat (Doctoral dissertation).

Ariyanti, S.R., 2017. Preservasi Naskah Kuno di Perpustakaan Rekso Pustaka Surakarta sebagai Upaya Penyelamatan Aset Keraton Pura Mangkunegaran Surakarta. LIBRARIA: Jurnal Ilmu Perpustakaan Dan Informasi, pp.25-35.

Atmi, R.T., Evaluasi Workshop Badan Arsip dan Perpustakaan Jawa Timur sebagai Bentuk Knowldge Sharing dari Kebijakan Preservasi Lokal Jatimuran Evaluation of The Library and Archives of East Java's Workshop as A Knowledge Sharing Form of Jawatimuran Local Wisdom Preservation.

Bahar, H. and Mathar, T., 2015. Upaya pelestarian naskah kuno di badan perpustakaan dan arsip daerah provinsi sulawesi selatan. Khizanah al-Hikmah: Jurnal Ilmu Perpustakaan, Informasi, dan Kearsipan, 3(1), pp.89-100.

Bella, K.O., 2017. Peranan perpustakaan dan museum tembakau dalam pelestarian kebudayaan kota jember. BIBLIOTIKA: Jurnal Kajian Perpustakaan dan Informasi, 1(1), pp.42-57.

Buang, M., 2018. Pelestarian bahan pustaka di museum balaputera dewa Sumatera Selatan. IQRA: Jurnal IImu Perpustakaan dan Informasi (e-Journal), 12(1), pp.99-114.

Christiani, L., 2020. Preservasi, Konservasi dan Restorasi Dokumen di Rekso Pustaka. Anuva: Jurnal Kajian Budaya, Perpustakaan, dan Informasi, 4(3), pp.371-382.

Desriyeni, D., 2018. Community Participation in Preserving Minangkabau Manuscripts in Nagari Koto Padang, Dharmasraya Regency, West Sumatra. Record and Library Journal, 4(2), pp.99-107.

Dureau, J.M. and Clements, D.W., 1986. Principles for the Preservation and Conservation of Library Materials. IFLA Professional Reports, No. 8.

Eden, P. and Feather, J. 1997. Preservation Policies and Strategies in British Archives and Records Offices: a Survey. Available: http://ehostvgw4. epnet.com

Fatmawati, E., 2017. Analisis Kebutuhan Pelestarian Bahan Perpustakaan Tercetak. Pustabiblia: Journal of Library and Information Science, 1(1), pp.7-27.

Hapsari, N.F.A. and Ariyani, C.L.T., 2018. Urgency Preservation of Digital Archives. Record and Library Journal, 4(2), pp.127-138.

Haryanto, H., 2015. PRESERVASI KOLEKSI GREY LITERATURE DALAM KESIAGAAN MENGHADAPI BENCANA DI PERPUSTAKAAN PERGURUAN TINGGI. Jurnal IPI (Ikatan Pustakawan Indonesia), 2(2), pp.8-20.

Handisa, R.H., 2017. Evaluasi Tingkat Kesiapan 
Organisasi dalam Rangka Preservasi Digital (Studi Kasus Pada Unit Repositori Flinders Academic Commons Of Flinders University Library (FACFUL), Adelaide, Australia Selatan). Khizanah al-Hikmah: Jurnal Ilmu Perpustakaan, Informasi, dan Kearsipan, 5(2), pp.176-186.

Hermawan, A., 2018. Sebuah Upaya Mempertahankan Identitas Nasional: Pelestarian Indegenous Knowledge melalui Pengembangan Teknologi pada Perpustakaan Nasional. Pustabiblia: Journal of Library and Information Science, 2(2), pp.277-295.

Heriyanto, H., 2020. Gaok's Oral Tradition Document Management as a Manifestation Of Cultural Preservation in The Library. Record and Library Journal, 6(1), pp.89-98.

Hendrawati, T., 2019. Digitalisasi Manuskrip Nusantara Sebagai Pelestari Intelektual Leluhur Bangsa. Media Pustakawan, 25(4), pp.21-29.

Hidayah, N. and Saufa, A.F., 2019. Preservasi Digital Arsip Naskah Kuno: Studi Kasus Preservasi Arsip di Badan Arsip dan Perpustakaan Provinsi Jawa Tengah. JIPI (Jurnal IImu Perpustakaan dan Informasi), 4(1), pp.41-51.

Hidayatullah, F., Nashihuddin, W. and Putra, K.A.D., 2020. Kegiatan Pelestarian dan Promosi Candi Kimpulan di Area Perpustakaan Universitas Islam Indonesia. Anuva: Jurnal Kajian Budaya, Perpustakaan, dan Informasi, 4(2), pp.141-152.

Ibrahim, A., 2013. Perawatan dan pelestarian bahan pustaka. Khizanah Al-Hikmah: Jurnal IImu Perpustakaan, Informasi, Dan Kearsipan, 1(1), pp.77-90.

Irhandayaningsih, A., 2018. Pelestarian kesenian tradisional sebagai upaya dalam menumbuhkan kecintaan budaya lokal di masyarakat Jurang Blimbing Tembalang. Anuva: Jurnal Kajian Budaya, Perpustakaan, dan Informasi, 2(1), pp.19-27.

Lemlit trisakti, Jurnal Terakreditasi SINTA, http:// lemlit.trisakti.ac.id/jurnal-terakreditasi-sinta/, diakses 29 November 2020

Maryono, M. and Pramono, M., 2020. Pengembangan website koleksi langka Perpustakaan UGM sebagai preservasi digital heritage menuju era industri 4.0. Jurnal Kajian Informasi \& Perpustakaan, 8(1), pp.1-20.

Muliyadi, I., 2013. Revitalisasi Peran Stake Holders Perpustakaan Sebagai Upaya Pelestarian Warisan Budaya Bangsa dalam Rangka Membangun Kerjasama Perpustakaan di Kawasan Asia Tenggara. Khizanah al-Hikmah: Jurnal IImu Perpustakaan, Informasi, dan Kearsipan, 1(1), pp.71-76.

Musrifah, M., 2017. Strategi Preservasi Digital di Perpustakaan UIN Sunan Kalijaga Yogyakarta. Khizanah al-Hikmah: Jurnal Ilmu Perpustakaan, Informasi, dan Kearsipan, 5(1), pp.67-83.

Nashihuddin, Wahid. "Analisis terbitan berkala bidang ilmu perpustakaan yang terbit di Indonesia." Majalah WIPA: Wahana Informasi Perpustakaan UAJY 19 (2015).

Noeraida, N. and Sungkono, A., 2020. Analisis Pemanfaatan Repositori untuk Preservasi Pengetahun Nuklir di BATAN. Media Pustakawan, 27(1), pp.69-85.

Noprianto, E. and Adiguna, I.K.G., 2021. Preservasi Arsip Foto Digital Individual: Kajian Pada Mahasiswa MIP UGM angkatan 2018-2019. Jurnal Pustaka Budaya, 8(1), pp.54-63.

Nurwahyuningsih, R. and Ismayati, N., 2019. EVALUASI KEGIATAN PRESERVASI FISIK NASKAH KUNO DI PERPUSTAKAAN NASIONAL RI MENGGUNAKAN MODEL CIPP (CONTEXT, INPUT, PROCESS, PRODUCT). Bibliotech: Jurnal IImu Perpustakaan dan Informasi, 4(1).

Oktaningrum, E.D. and Perdana, F., 2017. Preservasi koleksi bahan pustaka akibat bencana alam di Perpustakaan SDN Kudang Tasikmalaya. Jurnal Kajian Informasi \& Perpustakaan, 5(1), pp.23-36.

Priatna, Y., 2017. Melek Informasi Sebagai Kunci Keberhasilan Pelestarian Budaya Lokal. Publi- 
cation Library and Information Science, 1(2), pp.37-43.

Primadesi, Y., 2013. Preservasi pengetahuan dalam tradisi lisan seni pertunjukan randai di Minangkabau Sumatera Barat. Jurnal Kajian Informasi \& Perpustakaan, 1(2), pp.179-187.

Ratmono, D., 2019. Tinjauan Pemanfaatan Digital Printing dalam Pelestarian Majalah Terjilid Koleksi Perpustakaan Nasional RI. Media Pustakawan, 24(3), pp.67-76.

Rifauddin, M. and Pratama, B.A., 2020. Strategi preservasi dan konservasi bahan pustaka di dinas kearsipan dan perpustakaan kabupaten trenggalek. JURNAL ILMU PERPUSTAKAAN (JIPER), 2(1).

Pawitro, U., 2015. Preservasi-Konservasi Bangunan Bersejarah dan Pengelolaan Kawasan Kota Lama.

Prastika, F., Lestari, I. and Kurniawan, T., 2017. Konservasi koleksi lukisan pada kelompok kerja pelestarian bahan pustaka di UPT Perpustakaan Proklamator Bung Karno Blitar-Jawa Timur. BIBLIOTIKA: Jurnal Kajian Perpustakaan dan Informasi, 1(2), pp.48-52.

Putra, D.A., Andajani, K. and Istiqomah, Z., 2017. Implementasi Preservasi Digital Koleksi Karya Ilmiah Di Perpustakaan Maulana Malik Inbrahim Malang. BIBLIOTIKA: Jurnal Kajian Perpustakaan dan Informasi, 1(2), pp.28-33.

Purwani, I., 2020. Penentuan Skala Prioritas Preservasi Upaya Perlindungan Nilai Informasi Koleksi Di Perpustakaan Nasional. Media Pustakawan, 19(2), pp.26-29.

Purwono, P., 2020. Pelestarian Jangka Panjang Dan Aksesibilitas Isi Informasi Dengan Teknologi. Media Pustakawan, 17(1\&2), pp.53-64.

Putra, P. (2013). Preservasi Digital Arsip Peta (Blue Print) Di Kantor Arsip Universitas Indonesia. Jurnal IImu Informasi, Perpustakaan, dan Kearsipan, 12(3).
Ratnawati, S. and Rahmawati, Y., 2015. Digital Preservation of Photojournalism Case Study of the Kompas Daily. Record and Library Journal, 1(2), pp.183-192.

Rodiah, S., Khadijah, U.L.S. and Kurniasih, N., Naskah Kuno sebagai Identitas Budaya di Masyarakat Kabuyutan Ciburuy Bayongbong Kabupaten Garut Ancient Manuscript as Cultural Identity in The Community of Kabuyutan Ciburuy Bayongbong Garut Residence.

Rusmana, A., Rizal, E. and Khadijah, U.L., 2018. Literasi Sosial Budaya Masyarakat Penyangga Hutan Terhadap Pelestarian Taman Nasional Gunung Gede Halimun Salak (TNGHS). Record and Library Journal, 3(2), pp.116-126.

Saputra, D.F., 2019. Preservasi Konten Lokal di Perpustakaan Perguruan Tinggi (Studi Kasus Medical Knowledge Center UPN Veteran Jakarta). Pustabiblia: Journal of Library and Information Science, 3(1), pp.17-28.

Sedana, I.N., Damayani, N.A. and Khadijah, U.L.S., 2013. PRESERVASI BERBASIS KEARIFAN LOKAL (STUDI KASUS MENGENAI PRESERVASI PREVENTIF DAN KURATIF MANUSKRIP LONTAR SEBAGAI WARISAN BUDAYA DI KABUPATEN KLUNGKUNG BALI). Jurnal Kajian Informasi \& Perpustakaan, 1(1), pp.91-106.

Setyawan, H., 2014. Preservasi Material Fotografi. Shaura, R.K., Febriyanto, F. and Kurniawan, H., 2018. Preservasi Pengetahuan Document Controller untuk Performa Organisasi. Khazanah: Jurnal Pengembangan Kearsipan, 11(1), pp.13-25.

Sinta Ristek Dikti, Jurnal Perpustakaan dan informasi, https://sinta.ristekbrin.go.id/journals?q=perpustakaan+dan+informasi\&search $=1 \&$ sinta $=\& p u b=\& c i t y=\& i s s n=$, diakses 28 November 2020

Sukaesih, Y.W. and Agus Rusmana, N., 2016. Preservasi Naskah Kuno Sebagai Upaya Pembangunan Knowledge Management:-( Studi Kegiatan Preservasi Naskah Kuno Oleh 
Masyarakat Sebagai Upaya Pembagunan Knowledge Management). RECORD AND LIBRARY JOURNAL E-ISSN 2442, $5168(2)$, p.022.

Suliestyowati, L., 2020. Naskah Kuno Sebagai Warisan Budaya Bangsa (Naskah Kuno Digital di Frankfurt Book Fair 2015). Media Pustakawan, 21(3 \& 4), pp.75-79.

Susilawati, H., 2017. Preservasi Naskah Budaya Di Museum Sonobudoyo. AL Maktabah, 2(2).

Sumarni, S. and Rahmi, L., 2018. PERPUSTAKAAN DIGITAL "ISU PRESERVASI DIGITAL" Alasan, Proses dan Tantangan Ke depan. Shaut Al-Maktabah: Jurnal Perpustakaan, Arsip dan Dokumentasi, 10(2), pp.119-132.

Susanti, S., Mulyana, D. and Damayani, N.A., 2013. Penulis sunda sebagai pelestari budaya. Jurnal Kajian Informasi \& Perpustakaan, 1(2), pp.207215.

Syarif, V.D.P., 2016. Peran Pemerintah Dalam Menyelamatkan Naskah Kuno Minangkabau Pasca Gempa Pada Untuk Pelestarian Budaya Masyarakat Minangkabau. Pustakaloka, 7(1), pp.93-100.

Wahdah, S., 2019. Preservasi Naskah Kuno (Manuskrip) Kalimantan Selatan (Studi Kasus pada Dinas Perpustakaan dan Kearsipan Provinsi dan Museum Lambung Mangkurat Kalimantan Selatan). Antasari Press, pp.vii-64.

Yuliati, D., 2019. Pelestarian Candi Ngempon dan Pemanfaatannya untuk Atraksi Pariwisata. Anuva: Jurnal Kajian Budaya, Perpustakaan, dan Informasi, 3(3), pp.223-231.

Zalmi, N., 2019. PRESERVASI BAHAN PUSTAKA DI PERPUSTAKAAN PUSAT UIN IMAM BONJOL PADANG (STUDI KASUS KERUSAKAN BAHAN PUSTAKA KARENA FAKTOR BIOTIS). Shaut Al-Maktabah: Jurnal Perpustakaan, Arsip dan Dokumentasi, 11(2), pp.139-151.

Zen, Z., 2013. Cacah Ulang, Penyiangan dan Preservasi. Jurnal Ilmu Informasi, Perpustakaan, dan Kearsipan, 12(3). 